\title{
Research on the University Innovation and Entrepreneurship Education Comprehensive Evaluation Based on AHP Method
}

\author{
Ben Niu, Qianying Liu, and Yiming Chen
}

\begin{abstract}
Nowadays, innovation and entrepreneurship education in colleges and universities has been greatly valued and has obtained large-scale development in China. Meanwhile, "double innovation" education also has some worrying phenomena such as low quality and slow development. Systematic and scientific evaluation system is an important mean to ensure the effectiveness of entrepreneurship education, but it is still quite scarce. Therefore, this paper proposed an effective and comprehensive evaluation system to carry out the evaluation of entrepreneurship education in universities, so as to monitor the implementation process of entrepreneurship education and provide valuable feedback to promote the integrity of the "double innovation" education system. Afterwards, we used AHP and Delphi method to analyze the importance of the components of the evaluation system. Then, we conducted an empirical analysis, using the previous evaluation system, Delphi method and questionnaire survey to evaluate innovation and entrepreneurship education in Shenzhen University, and gave the results analysis. Finally, according to the survey results, this paper gave a series of analysis and suggestions, hoping to accelerate the development of "double innovation" education.
\end{abstract}

Index Terms-Innovation and entrepreneurship education, evaluation system, analytic hierarchy process.

\section{INTRODUCTION}

Nowadays, since premier Li Keqiang from China put forward the slogan of "Mass entrepreneurship and innovation" at the Davos Forum in Summer in 2014, the government has successively proposed the implementation of national-level college students' innovation and entrepreneurship training program, deepening the education reforms of universities, and constructing demonstration bases for universities and research institutes. In a word, colleges and universities actively carry out "double innovation" education. And "double innovation" means innovation and entrepreneurship.

However, most colleges and universities have some misunderstandings about "double innovation" education. Many people think that "double innovation" is to encourage students to start businesses, or even practice activities after class. In the course of education, problems such as weak cultural atmosphere, lack of professional knowledge combination, shortage of teachers, and losing the emphasis

Manuscript received January 10, 2019; revised July 2, 2019.

Ben Niu and Qianying Liu are with College of Management and Greater Bay Area International Institute of Innovation, Shenzhen University, Shenzhen, 518060, China (e-mail: drniuben@gmail.com, Qianying_Liu@163.com).

Yiming Chen is with Greater Bay Area International Institute of Innovation, Shenzhen University, Shenzhen, 518060, China (e-mail: 309770276@qq.com). on institution building and post-control. This has led to the unsatisfactory phenomenon of low quality and slow development of "double innovation" education.

Since the traditional teaching system and content can no longer meet the needs, many scholars are studying the reform methods of existing teaching in universities, including the study of theory, curriculum system and practice reform [1], [2], comprehensive practical teaching system [3], the characteristics and prospects discipline system [4]. Obviously, a systematic evaluation system can correctly guide the education reform [5]. However, the research on the "double innovation" education evaluation is quite rare. Without doubt, it has become an urgent need to resolve the contradiction.

AHP is a framework for solving problems and a measurement theory [6]-[8] and is used as a decision analysis technique to evaluate complex multi-attribute options between one or more decision makers. Its greatest advantage is that it can handle the combination of qualitative and quantitative problems, and quantify the decision-maker's subjective judgment and experience. AHP has been widely used, especially for large-scale and trend-predicting problems involving multiple factors, standards, and scenarios [9]. At present, Liu etc. has offered employment of university students entrepreneurship education evaluation index system, it contains four primary indicators: curriculum, teacher, student and environment, 10 secondary indicators and 48 tertiary indicators [10]; Gao etc. had applied an improved three-scale AHP method. Although the calculation is simplified and the consistency test and adjustment are avoided, the accuracy is reduced [11]; Based on the AHP method, He etc. had studied the evaluation of entrepreneurial ability of Chinese agricultural higher vocational college students [12]. This paper aims to build a more time-sensitive evaluation system for education innovation and entrepreneurship, including the social environment, college construction and students themselves three aspects. The AHP method was used to rank the importance of the elements in the system. Delphi expert method and questionnaire were used to conduct empirical analysis, and the suggestions were given to prove the validity and usefulness of our study.

The remainder of this paper is organized as follows. The index analysis and index system of university innovation and entrepreneurship education evaluation is introduced in section II. Section III gives the detailed description of AHP analysis of education evaluation system. Section IV is the empirical analysis of the innovation and entrepreneurship education evaluation for Shenzhen University. Finally, we draw the conclusion and gave some suggestions in section $\mathrm{V}$. 


\section{UNIVERSITY INNOVATION AND ENTREPRENEURSHIP EDUCATION EVALUATION INDEX SYSTEM}

Innovative entrepreneurship education is a practical education, aiming at cultivating talents with basic entrepreneurial qualities and pioneering personality. In fact, the "double innovation" education system is a complex system, which is influenced by external and internal factors. This paper will study the "double innovation" education evaluation from the social environment, college construction and students themselves three aspects [11]. Based on this, 13 indicators were selected to construct the university innovation and entrepreneurship education evaluation index system. The hierarchy and indicators are shown in Table I.

The definitions and references of indicators are described as follow:C1- The influence of universities local culture on the awareness of innovation and entrepreneurship, and the degree of risk preference [11], [13], [14]; C2- The simplicity of universities local administrative examination and approval procedures, site support, financial support, and tax incentives [13]; C3- The availability of bank's low-interest loans, angels/risk investments, microfinance guarantees and local government venture funds [13]; C4- Universities local economic development level, talent market, orderly market trading rules, technical support [13]; C5- Equipped with high-quality innovative entrepreneurship education faculty, introducing successful entrepreneurs as part-time teachers [2], [11], [14], [15]; C6- Set up a sophisticated innovative entrepreneurship education curriculum system, innovative entrepreneurship education and training, teaching methods are interactive, case-based new ways [2], [11], [15]; C7Vigorously promote and carry out various innovation and entrepreneurial activities, and give students corresponding rewards and incentives [2], [11], [14]; C8- Provide adequate funding, a good entrepreneurial infrastructure, a school-enterprise cooperation platform based on industry, academia, and various safeguards [2], [11], [14]; C9- Have a good idea of innovative entrepreneur-ship education, campus culture and corresponding management system [11], [14]; C10- The ability to insight into opportunities, raise funds, manage and develop human resources, and awareness of innovation and entrepreneurship [14,15];C11- Increased rate of students with innovative results after entrepreneurship education [11], [15]; C12- After receiving entrepreneurship education, the proportion of students who choose to start a business as a percentage of the total students [11], [14], [15]; C13-Participation rate in teaching and entrepreneurial simulation, out-of-town research, etc. and attendance rate in innovative entrepreneurship education courses [11].

\section{A. Social Environment}

As the external environment of university education, social environment can greatly affect the action and consciousness of universities and students. The government plays a leading role in the environment and is an important supporter of university entrepreneurship education. The government, issued the incentives, simple administrative examination and approval procedure and so on policy, build a good culture and business environment to cultivate innovative talents; Financial industries will give more economic support to startups. while the market determines the opportunities and survival of startups. A favorable environment for competition and cooperation, enabling companies to grow vigorously.

TABLE I: UNIVERSITY INNOVATION AND ENTREPRENEURSHIP EDUCATION EVALUATION INDEX SYSTEM

\begin{tabular}{|c|c|c|}
\hline Destination Layer & Criterion Layer & Index Layer \\
\hline \multirow{11}{*}{$\begin{array}{c}\text { University } \\
\text { innovation and } \\
\text { entrepreneurship } \\
\text { education evaluation } \\
\text { (A) }\end{array}$} & \multirow[t]{3}{*}{$\begin{array}{c}\text { social } \\
\text { environment } \\
\text { (B1) }\end{array}$} & $\begin{array}{l}\text { Innovation and entrepreneurship } \\
\text { culture (C1) } \\
\text { Innovation and entrepreneurship } \\
\text { policy }(\mathrm{C} 2) \\
\end{array}$ \\
\hline & & Entrepreneurial Finance (C3) \\
\hline & & Entrepreneurial market (C4) \\
\hline & \multirow{4}{*}{$\begin{array}{l}\text { university } \\
\text { construction } \\
\text { (B2) }\end{array}$} & Teachers level (C5) \\
\hline & & $\begin{array}{l}\text { Course system construction } \\
\text { (C6) }\end{array}$ \\
\hline & & $\begin{array}{l}\text { Entrepreneurship competition, } \\
\text { projects (C7) } \\
\text { Construction of practice base } \\
\text { (C8) }\end{array}$ \\
\hline & & $\begin{array}{c}\text { Construction of university } \\
\text { entrepreneurial atmosphere and } \\
\text { system (C9) }\end{array}$ \\
\hline & \multirow{4}{*}{$\begin{array}{l}\text { Students } \\
\text { themselves } \\
\text { (B3) }\end{array}$} & $\begin{array}{l}\text { Innovation and entrepreneurship } \\
\text { ability (C10) }\end{array}$ \\
\hline & & $\begin{array}{l}\text { Increase rate of innovation } \\
\qquad(\mathrm{C} 11)\end{array}$ \\
\hline & & Rate of entrepreneurship (C12) \\
\hline & & $\begin{array}{c}\text { Rates of participation and } \\
\text { attendance (C13) }\end{array}$ \\
\hline
\end{tabular}

\section{B. University Construction}

As the internal environment of "double innovation" education, the university is the implementer of entrepreneurship education and the key factor for the success of education. At present, colleges urgently need to deepen institutional reforms, improve existing entrepreneurial education programs, equip professional "double innovation" education faculty, externally hire enterprise personnel, set up new curriculum system, and vigorously carry out entrepreneurial competitions, but also to cultivate a strong entrepreneurial atmosphere.

\section{Students Themselves}

As the object of innovation and entrepreneurship education in universities, students are the most important variables. Students' innovative entrepreneurship, entrepreneurial awareness, and employability are both the foothold of "double innovation" education and the source of enthusiasm for students to participate spontaneously in innovative education. Colleges must achieve the goal of cultivating innovative talents by improving students' creativity, output of innovation, proportion of entrepreneurship, and enthusiasm for participation.

\section{AHP ANALYSIS OF UNIVERSITY INNOVATION AND ENTREPRENEURSHIP EDUCATION EVALUATION SYSTEM}

The Analytic Hierarchy Process (AHP), which was widely used in the field of sociology, was proposed by the American operations researcher Sadie Saaty.T.L. in the early 1970s 
[6]-[8]. AHP analysis has the characteristics of combination of qualitative and quantitative analysis, and is suitable for the evaluation of innovation and entrepreneurship education. This paper uses AHP to evaluate innovation and entrepreneurship education in colleges and universities, and the process as follows: First, we find and analyze the relationship between various factors in the "double innovation" education system, and establish the hierarchical evaluation system shown in Table I. Then, through the Delphi method, the relative importance of the same level of indicators to the previous level is compared to construct the judgment matrix. After passing the consistency test, the single layer weight is calculated. Finally, the total ranking weight of the target is obtained from the top to the bottom.

\section{A. Building a Judgment Matrix}

For the comprehensive evaluation index system shown in Table I, we adopt the 1-9 scale method [16], and the specific content is shown in Table II. Through the expert scoring and reference to relevant research results and experience, the judgment matrix and weight of the criterion layer to the target layer are constructed and shown in Table III.

TABLE II: NUMERICAL SCALE SPECIFICATION IN AHP

\begin{tabular}{lll}
\hline \hline Scale & Definition & Explanation \\
\hline 1 & equal importance & $\begin{array}{l}\text { Both elements are equally important } \\
\text { One element is slightly more important } \\
\text { than the other } \\
\text { One element is obviously more } \\
\text { important than the other } \\
5\end{array}$ \\
7 & obvious importance & $\begin{array}{l}\text { One element is mightily more } \\
\text { important than the other } \\
\text { One element is absolutely more } \\
\text { important than the other }\end{array}$ \\
$2,4,6,8$ & $\begin{array}{l}\text { absolute importance } \\
\text { the middle of } \\
\text { above-mentioned }\end{array}$ & $\begin{array}{l}\text { the middle of above-mentioned } \\
\text { importance }\end{array}$ \\
$1 / b_{i j}$ & $\begin{array}{l}\text { scale } \\
\text { the reverse }\end{array}$ & $\begin{array}{l}\text { If the scale of element } i \text { to element } j \text { is } \\
b_{i j} \text { and vice versa } \\
\text { is } 1 / b_{i j}\end{array}$ \\
\hline \hline
\end{tabular}

\begin{tabular}{ccccc}
\multicolumn{5}{c}{ TABLE III: A-B's JUDGMENT MATRIX } \\
\hline \hline A & B1 & B2 & B3 & W \\
\hline B1 & 1 & $1 / 3$ & 3 & 0.2583 \\
B2 & 3 & 1 & 5 & 0.6370 \\
B3 & $1 / 3$ & $1 / 5$ & 1 & 0.1047 \\
\hline
\end{tabular}

\begin{tabular}{llll}
\hline$\lambda_{\max }=3.039$ & $\mathrm{CI}=0.0193$ & $\mathrm{RI}=0.58$ & $\mathrm{CR}=0.0370$ \\
\hline \hline
\end{tabular}

\section{B. Hierarchical Single Sorting and Its Consistency Test}

The meaning of hierarchical single ordering is the ranking weight of the relative importance of the same level factor to a factor of the previous level. After sorting, we need to perform a consistency check, which is to determine the allowable range of inconsistency in the judgment matrix. Usually, the consistency index $\mathrm{CI}$ is calculated to determine whether the matrix passes the consistency check. $\mathrm{CI}=0$, indicating that the judgment matrix has complete consistency; $\mathrm{CI}$ is close to 0 , and there is satisfactory consistency; the larger the CI, the more serious the inconsistency. The definition of $\mathrm{CI}$ is:

$$
C I=\frac{\lambda-n}{n-1} v
$$

To measure the size of the $\mathrm{CI}$, a random consistency indicator RI needs to be introduced, and the size of the RI varies with the order of the judgment matrix, as shown in Table IV:

TABLE IV: RANDOM CONSISTENCY INDEX RI STANDARD VALUE

\begin{tabular}{cccccc}
\hline Matrix dimension & 1 & 2 & 3 & 4 & 5 \\
RI & 0 & 0 & 0.58 & 0.90 & 1.12 \\
\hline
\end{tabular}

However, random factors may also lead to matrix inconsistency. Therefore, when testing the consistency of judgment matrix, the test coefficient CR which compare CI with RI should be introduced. If $\mathrm{CR}<0.1$, the judgment matrix is considered to be consistent, otherwise is [17]. The formula of $\mathrm{CR}$ is as follows

$$
C R=\frac{C I}{R I}
$$

In addition, in this paper, the maximum eigenvector and eigenvalue are calculated by the sum-product method [18]. First, we make the judgment matrix $\mathrm{A}=\left(a_{i j}\right)_{\mathrm{n}} \times_{\mathrm{n}}, \mathrm{B}=\left(b_{i j}\right)_{\mathrm{n}} \times_{\mathrm{n}}$, and normalize A by column, as in formula (3). Then sum the normalized A which is B by the line, as in formula (4), and then normalize the vector $\mathrm{W}$, as in formula (5), the obtained $\mathrm{W}=\left[W_{1}, W_{2}, \cdots, W_{n}\right]$ is the feature vector, and finally calculate the maximum eigenvalue is shown in equation (6).

$$
\begin{gathered}
b_{i j}=\frac{a_{i j}}{\sum_{i=1}^{n} a_{i j}} \quad(i, j=1,2, \cdots, \mathrm{n}) \\
\bar{W}_{i}=\sum_{j=1}^{n} b_{i j} \quad(i, j=1,2, \cdots, \mathrm{n}) \\
\bar{W}_{i}=\frac{\bar{W}_{i}}{\sum_{j=1}^{n} \bar{W}_{j}} \quad(i, j=1,2, \cdots, \mathrm{n}) \\
\lambda_{\max }=\sum_{i=1}^{n} \frac{(A W)_{i}}{n W_{i}} \quad(i, j=1,2, \cdots, \mathrm{n})
\end{gathered}
$$

According to this process, this paper constructs the judgment matrix of 13 indicators respectively belonging to B1 social environment, B2 college construction, and B3 students' own three criteria layers. The test results and weights are shown in Table V-VII:

TABLE V: JUDGMENT MATRIX OF C1-C4 INDICATORS UNDER B1 LAYER

\begin{tabular}{cccccc}
\hline B1 & C1 & C2 & C3 & C4 & W \\
\hline C1 & 1 & $1 / 5$ & $1 / 2$ & $1 / 7$ & 0.0630 \\
$\mathrm{C} 2$ & 5 & 1 & 3 & $1 / 2$ & 0.3005 \\
$\mathrm{C} 3$ & 2 & $1 / 3$ & 1 & $1 / 5$ & 0.1098 \\
$\mathrm{C} 4$ & 7 & 2 & 5 & 1 & 0.5267 \\
\hline
\end{tabular}

$\begin{array}{llll}\lambda_{\max }=4.020 & \mathrm{CI}=0.0067 & \mathrm{RI}=0.90 & \mathrm{CR}=0.0075\end{array}$

\section{The Overall Ranking of the Indicators to the Target Level}

According to the single-layer weight analysis, the importance degree of the index layer to the overall goal of university innovation and entrepreneurship education can be 
obtained, that is, the total order of levels. The calculation results are shown in Table VIII:

\begin{tabular}{ccccccc}
\multicolumn{6}{c}{ TABLE VI: JUDGMENT MATRIX OF C5-C9 INDICATORS UNDER B2 LAYER } \\
\hline \hline $\mathrm{B} 2$ & $\mathrm{C} 5$ & $\mathrm{C} 6$ & $\mathrm{C} 7$ & $\mathrm{C} 8$ & $\mathrm{C} 9$ & $\mathrm{~W}$ \\
\hline $\mathrm{C} 5$ & 1 & 4 & $1 / 2$ & 2 & 3 & 0.2583 \\
$\mathrm{C} 6$ & $1 / 4$ & 1 & $1 / 5$ & $1 / 3$ & $1 / 2$ & 0.0613 \\
$\mathrm{C} 7$ & 2 & 5 & 1 & 3 & 5 & 0.4312 \\
$\mathrm{C} 8$ & $1 / 2$ & 3 & $1 / 3$ & 1 & 2 & 0.1574 \\
$\mathrm{C} 9$ & $1 / 3$ & 2 & $1 / 5$ & $1 / 2$ & 1 & 0.0918 \\
\hline$\lambda_{\max }=5.068$ & $\mathrm{CI}=0.017$ & $\mathrm{RI}=1.12$ & $\mathrm{CR}=0.0152$ \\
\hline \hline
\end{tabular}

TABLE VII: JUDGMENT MATRIX OF C10-C13 INDICATORS UNDER B3 LAYER

\begin{tabular}{cccccc}
\hline \hline $\mathrm{B} 3$ & $\mathrm{C} 10$ & $\mathrm{C} 11$ & $\mathrm{C} 12$ & $\mathrm{C} 13$ & $\mathrm{~W}$ \\
\hline $\mathrm{C} 10$ & 1 & $1 / 2$ & $1 / 2$ & 2 & 0.1891 \\
$\mathrm{C} 11$ & 2 & 1 & 1 & 3 & 0.3509 \\
$\mathrm{C} 12$ & 2 & 1 & 1 & 3 & 0.3509 \\
$\mathrm{C} 13$ & $1 / 2$ & $1 / 3$ & $1 / 3$ & 1 & 0.1091 \\
\hline$\lambda_{\max }=4.010$ & & $\mathrm{CI}=0.0035$ & $\mathrm{RI}=0.90$ & & $\mathrm{CR}=0.0039$ \\
\hline \hline
\end{tabular}

TABLE VIII: SUMMARY OF THE WEIGHTS OF EVALUATION INDICATORS FOR UNIVERSITY INNOVATION AND ENTREPRENEURSHIP EDUCATION

\begin{tabular}{|c|c|c|c|c|}
\hline $\begin{array}{l}\text { Destination } \\
\text { Layer }\end{array}$ & $\begin{array}{l}\text { Criterion } \\
\text { Layer }\end{array}$ & Weight & Index Layer & $\begin{array}{l}\text { Synthetic } \\
\text { weight }\end{array}$ \\
\hline \multirow{13}{*}{$\begin{array}{l}\text { University } \\
\text { innovation and } \\
\text { entrepreneurshi } \\
\text { p education } \\
\text { evaluation } \\
\text { (A) }\end{array}$} & \multirow{4}{*}{$\begin{array}{c}\text { social } \\
\text { environment } \\
\text { (B1) }\end{array}$} & \multirow{4}{*}{0.2583} & $\begin{array}{c}\text { Innovation and } \\
\text { entrepreneurship } \\
\text { culture }(\mathrm{C} 1)\end{array}$ & 0.0163 \\
\hline & & & $\begin{array}{c}\text { Innovation and } \\
\text { entrepreneurship } \\
\text { policy }(\mathrm{C} 2)\end{array}$ & 0.0776 \\
\hline & & & $\begin{array}{c}\text { Entrepreneurial } \\
\text { Finance }(\mathrm{C} 3)\end{array}$ & 0.0284 \\
\hline & & & $\begin{array}{l}\text { Entrepreneurial } \\
\text { market (C4) }\end{array}$ & 0.1360 \\
\hline & \multirow{5}{*}{$\begin{array}{l}\text { university } \\
\text { construction } \\
\text { (B2) }\end{array}$} & \multirow{5}{*}{0.6370} & $\begin{array}{l}\text { Teachers level } \\
\text { (C5) }\end{array}$ & 0.1645 \\
\hline & & & $\begin{array}{l}\text { Course system } \\
\text { construction } \\
\text { (C6) }\end{array}$ & 0.0390 \\
\hline & & & $\begin{array}{c}\text { Entrepreneurship } \\
\text { competition, } \\
\text { projects }(\mathrm{C} 7)\end{array}$ & 0.2747 \\
\hline & & & $\begin{array}{l}\text { Construction of } \\
\text { practice base } \\
\text { (C8) }\end{array}$ & 0.1003 \\
\hline & & & $\begin{array}{l}\text { Construction of } \\
\text { university } \\
\text { entrepreneurial } \\
\text { atmosphere and } \\
\text { system (C9) }\end{array}$ & 0.0585 \\
\hline & \multirow{4}{*}{$\begin{array}{c}\text { Students } \\
\text { themselves } \\
\text { (B3) }\end{array}$} & \multirow{4}{*}{0.1047} & $\begin{array}{l}\text { Innovation and } \\
\text { entrepreneurship } \\
\text { ability }(\mathrm{C} 10)\end{array}$ & 0.0198 \\
\hline & & & $\begin{array}{c}\text { Increase rate of } \\
\text { innovation }(\mathrm{C} 11)\end{array}$ & 0.0367 \\
\hline & & & $\begin{array}{c}\text { Rate of } \\
\text { entrepreneurship } \\
\text { (C12) }\end{array}$ & 0.0367 \\
\hline & & & $\begin{array}{l}\text { Rates of } \\
\text { participation and } \\
\text { attendance }(\mathrm{C} 13)\end{array}$ & 0.0114 \\
\hline
\end{tabular}

\section{EMPIRICAL ANALYSIS}

As a representative of the Frontier Innovation University, Shenzhen University is redefining the "Shenzhen Speed". The proportion of consecutive graduates of the school to self-employed is higher than many undergraduate colleges, and the innovation achievements have continued to grow for many years. In the construction of teaching, Shenzhen University established the Guangdong Province Talent Training Model Innovation Experimental Zone, and integrated innovation and entrepreneurship education into the talent training plan. From the entrepreneurial practice, the university supports the whole process of student entrepreneurship, invites entrepreneurs to share experiences, and promotes the implementation of "College Students Innovation and Entrepreneurship Training Program" and "Challenge Cup". Through the super-big innovation park, promoting the construction of campus creator space. This paper uses AHP, Delphi method and 200 online questionnaires to evaluate the innovation and entrepreneurship education of Shenzhen University, so as to discover the existing problems and guide the improvement direction of innovation and entrepreneurship education.

\section{A. Determine the Indicator Score Value}

This paper divides the evaluation criteria of Shenzhen University's innovation and entrepreneurship education into four levels, which constitutes the comment set: $=\{$ poor, general, better, good $\}$, the corresponding score is set to $(0-25],(25-50],(50-75],(75-100]$. According to the results of ten experts and 200 questionnaires from the questionnaire star website, the scores of each indicator are calculated as shown in Table IX:

TABLE IX: SUMMARY OF SCORES FOR INDICATORS AT EACH LEVEL

\begin{tabular}{|c|c|c|c|c|c|}
\hline $\begin{array}{l}\text { B1 layer } \\
\text { indicator }\end{array}$ & Score & $\begin{array}{l}\text { B2 layer } \\
\text { indicator }\end{array}$ & Score & $\begin{array}{l}\text { B3 layer } \\
\text { indicator }\end{array}$ & Score \\
\hline $\begin{array}{c}\text { Innovation } \\
\text { and } \\
\text { entrepreneur } \\
\text { ship culture } \\
\text { (C1) }\end{array}$ & $\begin{array}{c}72.121 \\
25\end{array}$ & $\begin{array}{c}\text { Teachers } \\
\text { level (C5) }\end{array}$ & $\begin{array}{c}67.748 \\
75\end{array}$ & $\begin{array}{c}\text { Innovation } \\
\text { and } \\
\text { entrepreneur } \\
\text { ship ability } \\
\text { (C10) }\end{array}$ & 64.13 \\
\hline $\begin{array}{l}\text { Innovation } \\
\text { and } \\
\text { entrepreneur } \\
\text { ship policy } \\
\text { (C2) }\end{array}$ & $\begin{array}{c}70.186 \\
25\end{array}$ & $\begin{array}{c}\text { Course } \\
\text { system } \\
\text { construction } \\
\text { (C6) }\end{array}$ & $\begin{array}{c}64.132 \\
5\end{array}$ & $\begin{array}{c}\text { Increase rate } \\
\text { of } \\
\text { innovation } \\
\text { (C11) }\end{array}$ & 67.03 \\
\hline $\begin{array}{l}\text { Entrepreneu } \\
\text { rial Finance } \\
\text { (C3) }\end{array}$ & $\begin{array}{c}66.347 \\
5\end{array}$ & $\begin{array}{c}\text { Entrepreneur } \\
\text { ship } \\
\text { competition, } \\
\text { projects }(\mathrm{C} 7)\end{array}$ & 70.11 & $\begin{array}{c}\text { Rate of } \\
\text { entrepreneur } \\
\text { ship (C12) }\end{array}$ & $\begin{array}{c}62.68 \\
25\end{array}$ \\
\hline \multirow[t]{2}{*}{$\begin{array}{l}\text { Entrepreneu } \\
\text { rial market } \\
\text { (C4) }\end{array}$} & \multirow[t]{2}{*}{$\begin{array}{c}70.678 \\
75\end{array}$} & $\begin{array}{c}\text { Construction } \\
\text { of practice } \\
\text { base }(\mathrm{C} 8)\end{array}$ & $\begin{array}{c}67.937 \\
5\end{array}$ & $\begin{array}{c}\text { Rates of } \\
\text { participation } \\
\text { and } \\
\text { attendance } \\
\text { (C13) }\end{array}$ & \multirow[t]{2}{*}{$\begin{array}{c}63.95 \\
25\end{array}$} \\
\hline & & $\begin{array}{c}\text { Construction } \\
\text { of university } \\
\text { entrepreneur } \\
\text { ial } \\
\text { atmosphere } \\
\text { and system } \\
\text { (C9) }\end{array}$ & $\begin{array}{c}69.202 \\
5\end{array}$ & & \\
\hline
\end{tabular}

\section{B. Determination and Analysis of Comprehensive Evaluation Values}

To calculate the comprehensive evaluation value of each layer, first from the index layer, according to formula 7 , the 
score $\mathrm{E} 1$ of $\mathrm{B} 1$ is calculated from $\mathrm{S} 1$ representing the scores of $\mathrm{C} 1-\mathrm{C} 4$ indicators and the weight $\mathrm{W} 1$, and so on, the score $\mathrm{E} 2$ of $\mathrm{B} 2$ and $\mathrm{E} 3$ of $\mathrm{B} 3$ is calculated. and then, according to the formula 8 , the score $\mathrm{E}$ of the total target is obtained by the score set $\mathrm{S}$ and the weight set $\mathrm{W}$ of the $\mathrm{B} 1-\mathrm{B} 3$. The specific results are shown in Table $\mathrm{X}$ :

$$
\begin{aligned}
& E_{1}=W_{1} * S_{1} \\
& E=\mathrm{W} * \mathrm{~S}
\end{aligned}
$$

TABLE X: SUMMARY OF COMPREHENSIVE SCORES AT ALL LEVELS

\begin{tabular}{ccccc}
\hline \hline Layer & B1 & B2 & B3 & A \\
\hline Comprehensive score & 70.15 & 68.71 & 64.62 & 68.65 \\
\hline \hline
\end{tabular}

The comprehensive evaluation score of Shenzhen University is 68.65 , which is within the range of better grade (50-75]. The comprehensive score gives us some inspirations: From the overall point of view, Shenzhen University's investment in "double innovation" education got large return. The entrepreneurial environment in Shenzhen is very good, but in the venture finance, the government needs to strengthen communication with financial institutions, increase the availability of bank low-interest loans, angels/ venture capital, microfinance guarantee Local government entrepreneurship funds to better assist college students in starting a business; In terms of university construction, Shenzhen University has more shortcomings. Although many entrepreneurial competitions and projects have been actively carried out, it is also necessary to introduce high-quality innovative and entrepreneurial education faculty and successful entrepreneurs as teachers, and to set up a comprehensive innovation and entrepreneurship education curriculum system, innovative teaching programs and strengthen the construction of practice base; The lack of students' own consciousness and ability is also a big problem in the education. First of all, according to the results, students are less motivated to participate in entrepreneurship courses and practice. Colleges must take improvement measures from the aspects of teaching methods, curriculum system and entrepreneurial atmosphere to improve students' enthusiasm and awareness of innovation and entrepreneurship, the quality of education and make a virtuous circle of education, and achieve the goal of improving students' ability to innovate and start a business eventually.

\section{CONCLUSION AND SUGGESTION}

This paper constructs an innovation and entrepreneurship education evaluation system from three levels, and selects 13 representative indicators. Then, using AHP and Delphi method to calculate the weight of each level, the results show five small aspects of entrepreneurship competition and projects, teachers' level, entrepreneurial market, construction of practice base, innovation and entrepreneurship policy have a tremendous impact on "double innovation" education. From a macro perspective, university construction has a decisive role in the quality of education, the second is social environment, and finally is the students' own consciousness and ability. This shows that "double innovation" education must firstly be based on university construction. Finally, through empirical analysis, we assessed the situation of innovation and entrepreneurship education in Shenzhen University, and monitored the implementation process of entrepreneurship education to guide the "double innovation" education. Based on the analysis results, we propose the following suggestions:

\section{A. Construct a Mechanism Integrating Innovation and Entrepreneurship Education with Professional Education}

Colleges should abandon the past cramming teaching system and systematically carry out the reform from the aspects of teaching concept, teaching content, teaching methods, teaching staff, and entrepreneurial practice. Diverse entrepreneurship courses and practices are implemented for corresponding professions to realize the individualization and refinement of education. At the same time, through the various entrepreneurial competitions and practices to cultivate college students' awareness and ability.

\section{B. Develop "Mass Creative Space" and Cultivate "Entrepreneurial Culture"}

Colleges and universities can set up an "innovation park", give financial and policy support, integrate off-campus entrepreneurial resources, and strengthen cultural exchanges and integration between universities and society. At the same time, we must carry out various entrepreneurial lectures, trainings, etc., increase innovation and entrepreneurship propaganda, explore advanced models of "double innovation", and create a strong cultural atmosphere.

\section{Establish an Entitative Management Agency}

An independent running Innovation and Entrepreneurship Education College can coordinate the entrepreneurial resources of the whole school, and uniformly formulate and implement the construction and reform of entrepreneurial talent training programs, education curriculum system, teacher team, entrepreneurship practice, so as to more effective and orderly manage the operation of education.

\section{Improve the Teaching Management and Evaluation System of Innovation and Entrepreneurship Education}

Universities should establish an evaluation mechanism for the innovation and entrepreneurship education, increase the weight of the "double innovation" education in the evaluation of teachers' titles, establish a credit mechanism composed of innovation, entrepreneurship and professionalism for students, and build the innovation and entrepreneurship educational reform projects identifying mechanism.

\section{E. Carry Out Continuous Education Evaluation}

Universities should evaluate "double innovation" education for improving the design and implementation of educational programs at different stages, so as to monitor the implementation process of entrepreneurship education and test the effectiveness in real time. And put forward valuable feedback to promote the soundness of the "double innovation" education system.

\section{CONFLICT OF INTEREST}

The authors declare no conflict of interest. 
Ben Niu proposed ideas for the research; Qianying Liu and Yiming Chen collected and analyzed the data; All the authors wrote this article together; all authors had approved the final version.

\section{ACKNOWLEDGMENT}

The work described in this paper was supported by Project of Innovation and Entrepreneurship Education Research Centre for University Student of Guangdong Province (2018A073825), Research Cultivating Project of Shenzhen Institute \& Information Technology (ZY201717), and Natural Science Foundation of Guangdong Province (2016A030310074).

\section{REFERENCES}

[1] B. Liu and N. Yan, "Study and practice of graduates' curriculum reform - Based on the integration of creativity, innovation, and entrepreneurship," Journal of Higher Education, pp. 13-15, 2018.

[2] N. Yan and B. Liu, "The theoretical and practical study of enterprise education and the relevant courses in colleges and universities," Journal of Higher Education, pp. 32-34, 2018.

[3] S. Yu, "Comprehensive practical teaching system design of international trade majors based on innovative and entrepreneurial ability cultivation," Journal of Higher Education, pp. 34-36, 2018.

[4] X. Lin, "A study of constructing advanced type curriculum system of innovation and entrepreneurship education," Journal of Teacher Education, vol. 3, pp. 65-70, 2016.

[5] D. Jin, "Experience and implication of the evaluation system of higher education and the mechanism of quality control in the UK," Educational Research, pp. 76-81, 2005.

[6] T. L. Saaty, "Axiomatic foundation of the analytic hierarchy process," Management Science, pp. 841-855, 1986.

[7] T. L. Saaty, "An exposition of the Ahp in reply to the paper remarks on the analytic hierarchy process," Management Science, vol. 36, pp. 259-268, 1990.

[8] T. L. Saaty, "What is the analytic hierarchy process?" International Proceedings of Mathematical Models for Decision Support, pp. 109-121, vol. 48, 1988.

[9] A. Emrouznejad and M. Marra, "The state of the art development of AHP (1979-2017): a literature review with a social network analysis," International Journal of Production Research, vol. 55, pp. 1-23, 2017.

[10] H. Liu, Y. Yang, and L. Chen, "AHP-based employment of university students entrepreneurship education evaluation index system," Northeast Normal University: Philosophy and Social Science Edition, pp. 227-232, 2012.

[11] K. Gao and J. Hua, "Study on the innovation and entrepreneurship education evaluation based on improved AHP method," Modern Education Management, pp. 61-64, 2015.
[12] Z. W. He, Y. Ren, J. P. Guo et al, "Evaluation of entrepreneurial ability of Chinese agricultural higher vocational college students based on AHP," Agrotechnical Economics, pp. 111-117, 2010.

[13] C. M. Liu and C. B. Li, "Research on college students entrepreneurial ecosystem evaluation index system," Mathematics in Practice and Theory, vol. 48, pp. 138-146, 2018

[14] F. L. Shu, Y. Lai, L. Jing et al., "Study on the evaluation system of college entrepreneurship education," Education Exploration, pp. 75-76, 2012.

[15] E. G. Zhang, "A preliminary study on the evaluation index system of innovation and entrepreneurship in higher vocational colleges," Education sciences, pp. 386, 2017.

[16] Z. Luo and S. Yang, "Comparative study on several scales in AHP," Systems Engineering-Theory \& Practice, vol. 24, pp. 51-60, 2004.

[17] T. L. Saaty, "A scaling method for priorities in hierarchical structures," Journal of Mathematical Psychology, vol. 15, pp. 234-281, 2000.

[18] Y. Wang, "Review of judgment matrix sorting methods," Management Sciences in China, pp. 101-114, 1995.

Copyright $\odot 2019$ by the authors. This is an open access article distributed under the Creative Commons Attribution License which permits unrestricted use, distribution, and reproduction in any medium, provided the original work is properly cited (CC BY 4.0).

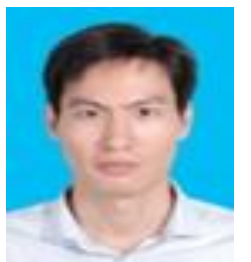

Ben Niu's principal research interests include evolutionary computation, innovation and entrepreneurship management, technology management. $\mathrm{He}$ is particularly interested in entrepreneurship education. He is currently professor at the College of Management and School of Entrepreneurship, Shenzhen University. $\mathrm{He}$ has published more than 60 peer-refereed papers at international journals since 2007 and four books.

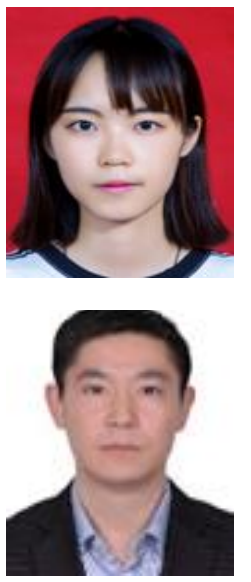

Qianying Liu received the bachelor's degree in engineering from Chongqing Jiao Tong University, China, in 2018. She is currently a graduate student in management science and engineering at the School of Management, Shenzhen University. Her research interests include evolutionary computation, as well as innovation and entrepreneurship management.

Yiming Chen is currently the director of the Management Committee of Shenzhen University Entrepreneurship Park. He is interested in constructing an innovation and entrepreneurship ecosystem in the university environment, innovation and entrepreneurship policies and platforms. He was awarded the "Shenzhen Leading Educator" and he was elected as National Outstanding Innovation and Entrepreneurship Educator in 2016. 